\title{
The Z.V. Davis-McPeek Site, an Early Caddoan Mound Site in the Little Cypress Creek Valley, Upshur County, Texas
}

Bo Nelson

Heritage Research Center, Stephen F. Austin State University

Timothy K. Perttula

Heritage Research Center, Stephen F. Austin State University

Follow this and additional works at: https://scholarworks.sfasu.edu/ita

Part of the American Material Culture Commons, Archaeological Anthropology Commons, Environmental Studies Commons, Other American Studies Commons, Other Arts and Humanities Commons, Other History of Art, Architecture, and Archaeology Commons, and the United States History Commons

Tell us how this article helped you.

This Article is brought to you for free and open access by the Center for Regional Heritage Research at SFA ScholarWorks. It has been accepted for inclusion in Index of Texas Archaeology: Open Access Gray Literature from the Lone Star State by an authorized editor of SFA ScholarWorks. For more information, please contact cdsscholarworks@sfasu.edu. 
The Z.V. Davis-McPeek Site, an Early Caddoan Mound Site in the Little Cypress Creek Valley, Upshur County, Texas

\section{Creative Commons License}

\section{(c) (1) (8)}

This work is licensed under a Creative Commons Attribution-NonCommercial 4.0 International License 


\section{The Z.V. Davis-McPeek Site, an Early Caddoan Mound Site in the Little Cypress Creek Valley, Upshur County, Texas \\ by}

Bo Nelson and Timothy K. Perttula

\section{INTRODUCTION}

The Z.V. Davis-McPeek site (41UR4/99) is an Early Caddoan period mound and habitation area located in northwest Upshur County. The mound is on a broad terrace along Little Cypress Creek, in the western portion of the Cypress Basin. Since the initial recording of the site some 60 years ago, there have been several different but limited investigations there, but none have been published. These limited investigations, coupled with the uncertainty of the site's exact location (see below), prompted the authors (with the able assistance of Mike Turner) to relocate the site, assemble known information about it, evaluate the current condition and integrity of the site's archeological deposits, and gather additional data on the location of any Caddoan habitation areas (no investigations were conducted on the mound itself). This effort is part of both a long-term systematic survey and testing program to gain a better understanding of Early Caddoan occupations in the Little Cypress Creek drainage, and the hope to formulate preservation measures for the site with the landowner's assistance.

\section{SITE RELOCATION}

The original Texas Archeological Research Laboratory (TARL) designation for the Z.V. Davis-McPeek site was 41UR4. The TARL plotting for the site was taken from a 1950s Upshur County road map. During the relocation of the site, it was determined that the TARL plotting was incorrect since it used distances along roads that did not exist in the 1930s. A replotting using the 1930s roads (now unpaved county roads) and the 1939 map by A.M. Woolsey showed that the mound site was actually farther to the east in the Little Cypress Creek valley. After consulting with TARL personnel, a trinomial was assigned to 
the correct location (41UR99). Since the old incorrect plotting was not retired, we have decided to refer to the Z.V. Davis-McPeek site by the trinomial 41UR4/99 to insure that the correct plotting is associated with the 1930s TARL records and files for the site.

\section{HISTORY OF SITE INVESTIGATIONS}

The Z.V. Davis-McPeek site was initially recorded as site No. 28B6-1 in June of 1931 by A.T. Jackson for the University of Texas (TARL records). There were artifactual materials apparently collected at that time, and site records note that a mound was also present. A Mr. H.M. Prince dug an undescribed burial with pottery vessels from the site before 1930. In 1934 permission was secured from the landowners for future investigations and possible excavations in the fall of 1934. However, in a letter to one of the landowners in November 1934 (TARL records), Jackson wrote that plans would be delayed until the spring of 1935. For unknown reasons, the spring 1935 investigations were never conducted by the University of Texas.

During the federal Works Progress Administration-University of Texas Project investigations in East Texas, A.M. Woolsey sent a postcard dated August 5, 1939, to A.T. Jackson stating he was in Pittsburg (Camp County) and would visit the Davis-McPeek site (TARL records). On August 6, 1939, Woolsey re-recorded the mound (Figure 1), obtained a surface collection, and re-secured permission for future investigations (TARL records). The Woolsey surface collection consisted of 35 ceramic sherds: 17 plain body sherds, one base, 11 punctated body sherds, one punctated-incised rim, four incised body sherds (one Kiam Incised and one Dunkin Incised), and one brushed body sherd (D.A. Story identification in TARL records). Although Woolsey re-obtained permission to conduct excavations at the Davis-McPeek site, again no further University of Texas investigations were conducted at the site.

In 1963, at the seventh Caddo Conference (Davis et al. 1971), Buddy Calvin Jones reported on his investigations at the "Spencer Davis Mound" site located in the Cypress 
Creek basin in northwest Upshur County (Guy 1990:80). The "Spencer Davis Mound" site is the same as what we are referring to as the Z. V. Davis-McPeek site. Jones reported

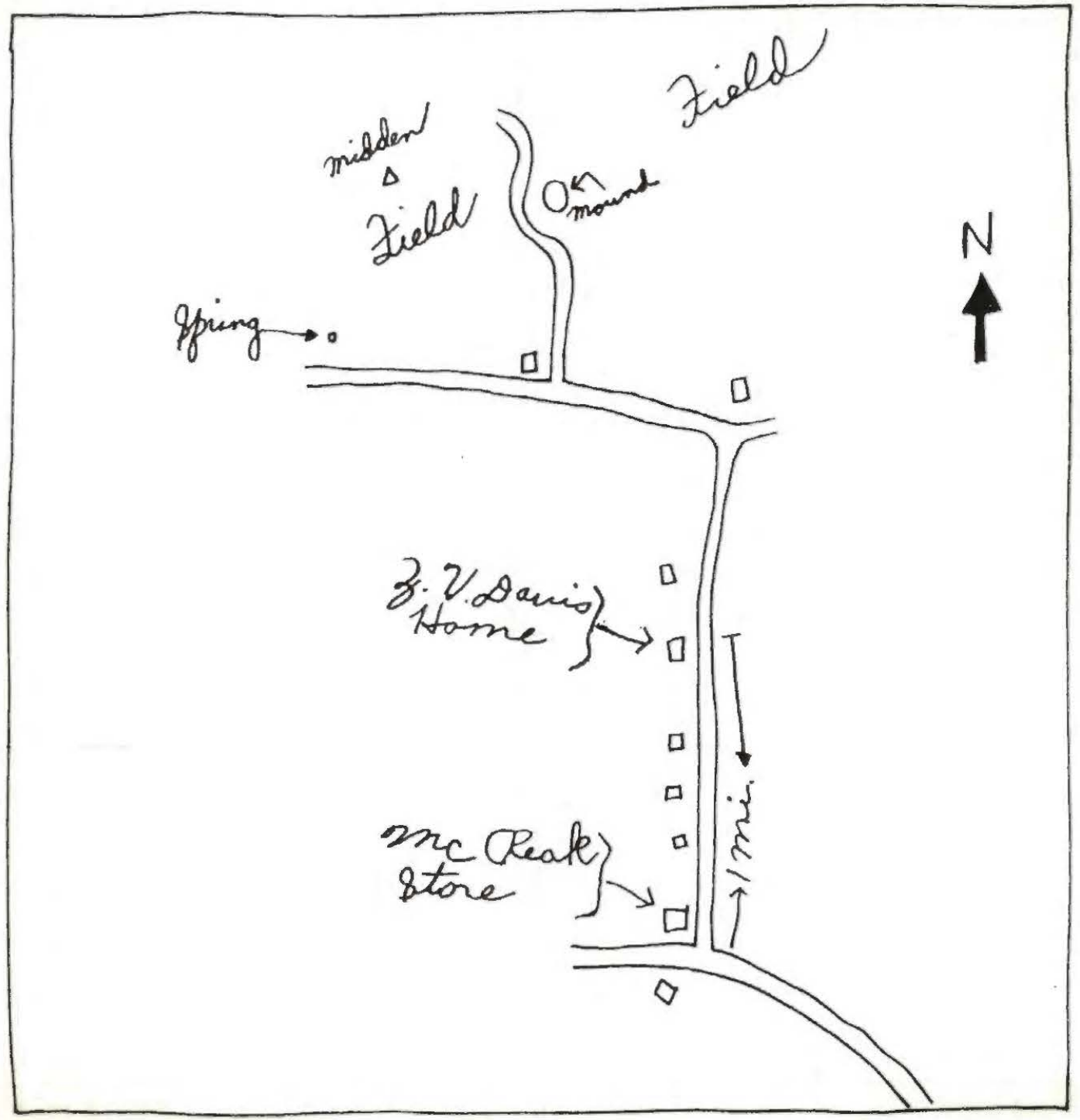

Figure 1. A.M. Woolsey's 1939 map of the mound and midden at the Z.V. DavisMcPeek site, local roads, homes, and the McPeek store.

finding a sub-mound Alto Focus burial containing two pottery vessels of the types Crockett Curvilinear-Incised and Holly Fine Engraved (Davis et al. 1971:103). He further related that vessels of the types Dunkin Incised, Crockett Curvilinear-Incised, and Weches 
Fingernail-Impressed were removed from the mound by other individuals (Davis et al. 1971:103). No further information is available from Jones' investigations, although the materials from the site are presumably in the Buddy Calvin Jones collection in Longview, Texas, now for sale by Mr. Jones.

After the publication of the proceedings of the seventh Caddo Conference, there was renewed interest in locating the "Spencer Davis Mound" reported by Jones. Bob D. Skiles, then director of the Wood County Archaeological Survey, relocated the mound and found an associated midden area (the artifacts from the midden are described below in the Artifact Analysis section of the paper); this midden may be the same as that depicted in Figure 1 by Woolsey. Although Skiles' work was limited, it did provide useful cultural materials for analysis to complement our investigations.

\section{INVESTIGATIONS}

The senior author and Mike Turner relocated the Davis-McPeek site in the spring of 1993. The mound was visible along a wooded fence line (the same fence line that divided the Z.V. Davis and McPeek fields in the 1930s) paralleling the terrace, with two terrace knolls to the north-northwest (Area A) and west (Area B) [Figure 2]. The mound itself is about $20 \times 13 \mathrm{~m}$ in size, and perhaps $3 \mathrm{~m}$ in height. In 1939, Woolsey reported that the mound was $50 \times 30 \times 15$ feet in size ( $15.2 \times 9.2 \times 4.6 \mathrm{~m})$, and made of sand (TARL files). The diference in size is probably the result of erosion and plowing over the last 60 years that has lowered the mound's height but increased its size in lateral dimensions.

After relocating the mound, a small surface collection was taken from the site area. Since the vast majority of the site is in pasture, only limited surface exposures were present; thus most of the surface artifacts from Z.V. Davis-McPeek were collected several hundred meters to the west-southwest of the mound along a road cut. 


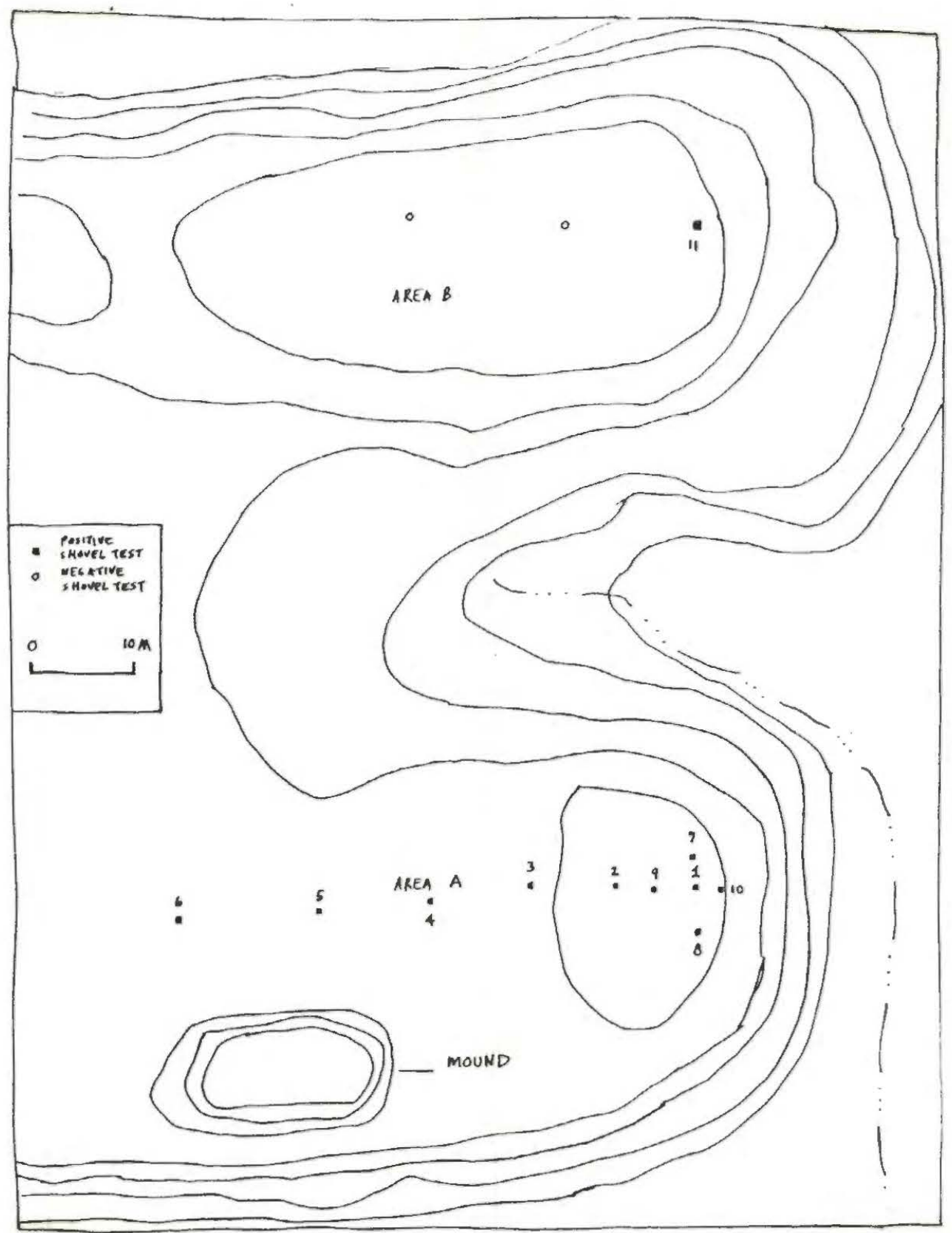

Figure 2. Area A and B at the Z.V. Davis-McPeek Site (41UR4/99) showing the location of the mound and the 1993 shovel tests.

In August 1993, the authors and Mike Turner returned to the site to carry out shovel test investigations to try to determine the presence, and location, of intact archeological 
deposits/habitation areas that may be associated with the use of the mound by Caddoan peoples. Thirteen shovel tests were excavated on the two terrace knolls, with most of the shovel tests placed in Area A to the west and north of the mound (see Figure 2).

The shovel tests averaged about $40 \times 40 \mathrm{~cm}$ in size, and they extended from 50-72 $\mathrm{cm}$ in total depth. Cultural materials were recovered in 11 of the 13 shovel tests, with most of the artifacts recovered in shovel tests 1, 7, and 9 in Area A and shovel test 11 in Area B (Table 1). In general, shovel testing documented that $50 \mathrm{~cm}+$ thick archeological deposits are present in both Area A and B. The site has a $15 \mathrm{~cm}$ thick plow zone over E1 and E2 dark brown sandy loam soil horizons with krotovinas and dispersed charcoal flecks; clay lamellae are present below $50 \mathrm{~cm}$ below surface (bs).

Table 1. Artifacts Recovered from

Z.V. Davis-McPeek Site

\begin{tabular}{|c|c|c|c|c|c|c|c|c|c|}
\hline Shovel Test & $\begin{array}{l}\text { Lithic } \\
\text { Debris }\end{array}$ & Tools & Fauna & $\begin{array}{l}\text { Charred } \\
\text { Nutshell }\end{array}$ & Charcoal & $\begin{array}{l}\text { Plain } \\
\text { Sherds }\end{array}$ & $\begin{array}{l}\text { Decorated } \\
\text { Sherds }\end{array}$ & Daub & Historics \\
\hline ST 1 & 16 & - & 27 & 6 & 3 & 12 & - & 282 & 1 \\
\hline ST 2 & 9 & - & - & 2 & - & - & 1 & 7 & - \\
\hline ST 3 & 5 & - & - & - & 1 & 1 & - & 1 & - \\
\hline ST 4 & 5 & - & - & - & - & - & - & - & - \\
\hline ST 5 & 5 & - & - & - & - & - & - & 1 & - \\
\hline ST 6 & 5 & - & - & - & - & 5 & - & - & - \\
\hline ST 7 & 7 & - & - & . & 1 & 4 & 2 & 84 & - \\
\hline ST 8 & 8 & 1 & - & 1 & 3 & 2 & 1 & 35 & 1 \\
\hline ST 9 & 6 & - & - & - & - & 3 & - & 45 & - \\
\hline ST 10 & 8 & - & - & - & 4 & 5 & 3 & 23 & - \\
\hline ST 11 & 18 & 1 & 5 & 1 & - & 31 & 3 & 10 & - \\
\hline SURFACE & 15 & 1 & - & - & - & 1 & 2 & - & 41 \\
\hline TOTALS & 107 & 3 & 32 & 10 & 12 & 64 & 12 & 488 & 43 \\
\hline
\end{tabular}

In addition to recovering 710 artifacts from the shovel tests, these investigations also documented a $50 \mathrm{~m}^{2}$ burned clay and daub concentration at the north end of Area A. This concentration probably marks the location of an Early Caddoan period house on the knoll. This area warrants further investigations. 


\section{ARTIFACT ANALYSIS}

This section describes the artifacts recovered from the Z.V. Davis-McPeek site from Bob D. Skiles' investigations in the 1970s, and the materials found during our 1993 surface and shovel testing effort at the site. Although the prehistoric artifact assemblage from the site is small, it appears to belong exclusively to a Formative or Early Caddoan period occupation.

\section{Wood County Archaeological Survey Collection}

A small assortment of Caddoan ceramics and stone tools were collected from the Davis-McPeek site in the late 1970s by Bob D. Skiles, then director of the Wood County Archaeological Survey. Skiles collected the artifacts from a midden area (which has not been relocated) an unknown distance west-northwest of the mound at the Davis-McPeek site.

Arrowpoint (no. of specimens $=1$ )

The stem and blade of an Alba arrowpoint is in the collection (Figure 3). The arrowpoint was made on a tertiary flake of a gray chert that probably is not of local origin (Perttula 1984). The bulb of percussion of the flake was trimmed to form the slightly bulbous stem of the tool. Dimensions: length, unknown; blade width, $12 \mathrm{~mm}$; thickness, 2 $\mathrm{mm}$; stem width, $5.5 \mathrm{~mm}$.

Long-stemmed pipe (no. of specimens=1)

The piece is the butt-end to a Red River style Caddo long-stem pipe. It is broken where the butt-end would meet the bowl of the pipe. The long-stem pipe sherd is tempered with finely crushed bone, and the surface of the pipe appears to have been burnished. Dimensions: exterior bore-hole diameter, $8.7 \mathrm{~mm}$; interior bore-hole diameter, $4.5 \mathrm{~mm}$. 


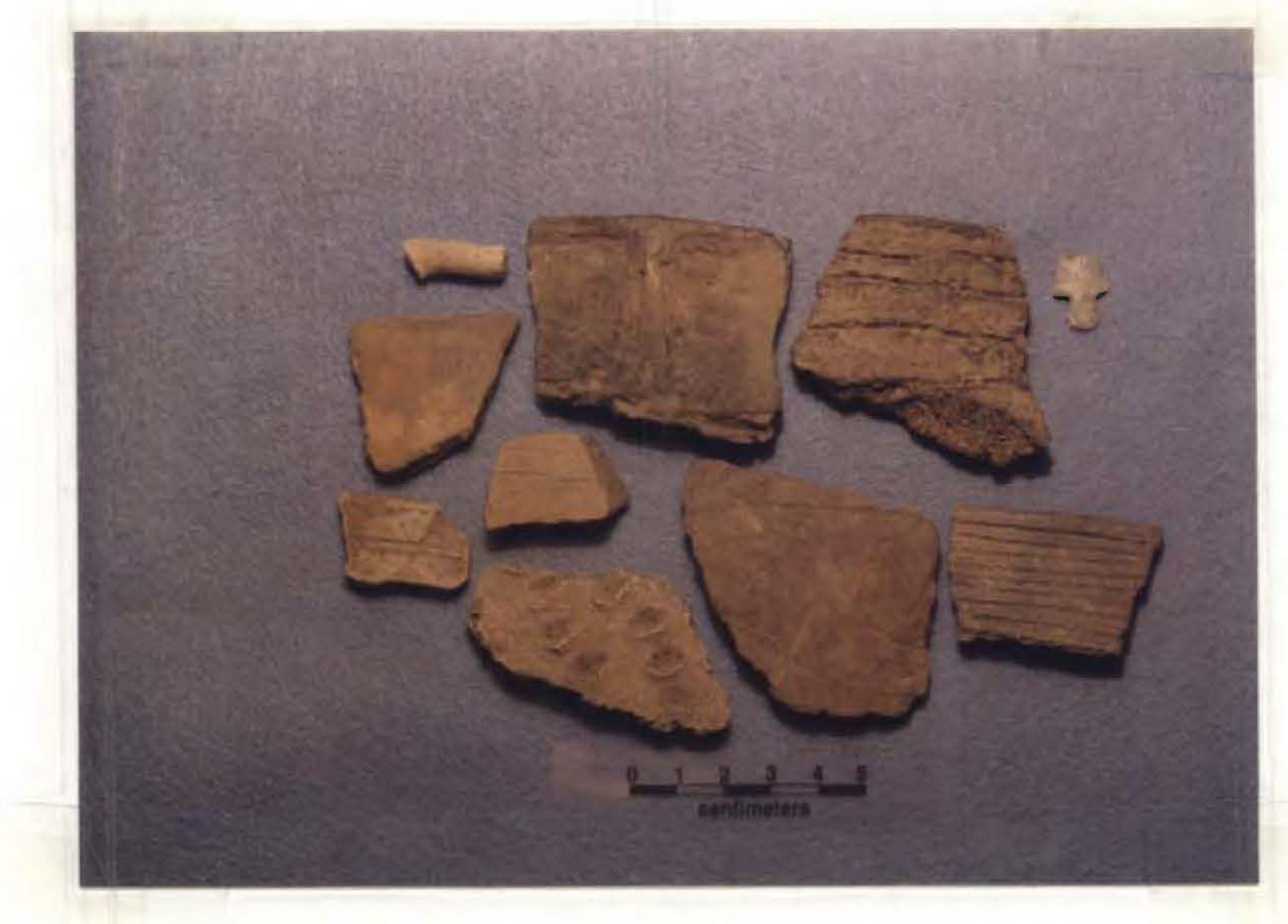

Figure 3. The Wood County Archaeological Survey Collection from the Z.V. Davis-McPeek Mound site.

Pottery sherds (no. of specimens: 8 )

Among the eight pottery sherds in the Skiles collection are five rims and three body sherds. Each of the sherds are discussed individually, starting with the rim sherds (see Figure 3).

The first rim sherd is from a large jar decorated with poorly executed and widely separated horizontal incised lines. The rim is slightly everted with a thick, flat, lip that has been beveled on the interior of the piece. The sherd is tempered with abundant inclusions of grog (i.e., crushed sherds), and the paste appears to be sandy. Dimensions: thickness, 8.5 $\mathrm{mm}$; lip width, $5.6 \mathrm{~mm}$.

The second rim sherd is from a well-made bowl that has been burnished on the interior. The vessel is decorated with at least eight closely-spaced, overhanging incised lines beginning immediately below the lip; the decorative treatment is reminiscent of the Coles Creek, Hardy, and Mott varieties of Coles Creek Incised from the Lower Mississippi Valley and the lower Red River (Williams and Brain 1983:Figure 5.56, 5.61, and 5.63) as 
well as Davis Incised (Suhm and Jelks 1962:Plate 18g). The rim is standing with a slightly everted lip. Observed temper of the bowl is finely-crushed bone and grog. Dimensions: thickness, $8.0 \mathrm{~mm}$; lip width, $3.8 \mathrm{~mm}$; orifice diameter, $16 \mathrm{~cm}$.

The next rim sherd has a poorly formed appliqued pseudo-handle immediately below the lip of this everted rim jar. The "handle" is $26 \mathrm{~mm}$ in length and $7 \mathrm{~mm}$ in width. The rim is otherwise plain, although it has been roughly smoothed with a stick on both the exterior and interior of the vessel. Immediately below the "handle" are several deeply incised lines at the rim-body juncture; the incised lines are diagonal to the lip of the jar. Dimensions: thickness, $7 \mathrm{~mm}$; lip width, $7 \mathrm{~mm}$; estimated orifice diameter, $18 \mathrm{~cm}$. The rim sherd is tempered with small amounts of grit and grog.

The fourth rim sherd has a single horizontal incised line about $8 \mathrm{~mm}$ below the lip. The rim appears to be from a hemispherical bowl with a rounded and slightly everted rim form. It is tempered with finely crushed grog. Dimensions: thickness, $4.2 \mathrm{~mm}$; lip width, 3 $\mathrm{mm}$.

The fifth rim sherd is from an undecorated bowl tempered with grog. Both interior and exterior vessel surfaces have been scraped and smoothed, and there is a smudged area on the interior just below the lip. The rim is standing, with a flat lip. Dimensions: thickness, $6 \mathrm{~mm}$; lip width, $6 \mathrm{~mm}$.

The three body sherds are from three different vessels, as each has a different exterior decorative treatment. The first has parallel rows of large, deep "fingernail" punctates; the punctates pushed up a ridge of clay to one side of the punctate. The punctated body sherd is from a grog-tempered jar. Dimensions: thickness, $9.3 \mathrm{~mm}$.

The second grog-tempered body sherd has three irregularly spaced parallel-incised lines for decoration. It is from a thick vessel $(9.5 \mathrm{~mm})$, probably a jar. Hematite inclusions were also added to the vessel's sandy paste.

The last body sherd has a complicated engraved design on a hemispherical bowl. The decoration includes a series of curvilinear engraved lines separating parallel diagonal 
engraving that appears to be part of a "scroll" motif. This sherd is identified as Spiro Engraved (see Suhm and Jelks 1962:Plate 74b and e). The sherd is tempered with finely crushed grog.

Comments on the Wood County Archaeological Survey Collection

The small lithic and ceramic assemblage from the Davis-McPeek site midden represents a Formative or Early Caddoan period occupation. This is based on the recovery of the Alba arrowpoint, the common occurrence of horizontally incised ceramics, and the Spiro Engraved type. Story (1990:334) dates Formative and Early Caddoan sites in Northeast Texas to between A.D. 800-1200. To the present time, few Formative-Early Caddoan sites are known in the Little Cypress Creek basin. Further study of the Z.V. Davis-McPeek midden and associated artifact assemblage should contribute significant new information on the development and fluorescence of Caddoan societies in the region (see Perttula 1993).

\section{Investigations}

Table 1 lists the numbers and types of artifacts recovered in surface collection $(\mathrm{N}=60)$ and shovel test $(\mathrm{N}=710)$ investigations in 1993 at the Davis-McPeek site. In the surface collection, historic ceramics and glass, and lithic debris, were most common, while daub, lithic debris, and prehistoric pottery sherds were most frequent.

Lithic Debitage (no. of specimens=107)

The lithic debitage represents the by-products of stone tool manufacture and resharpening activities at the site. Most of the debitage is found in the same shovel tests that have the highest numbers of other artifacts (i.e., daub and sherds), perhaps suggesting that multiple cultural activities were concentrated in the same areas on the site. The debitage is from locally-derived quartzites, petrified wood, and cherts. 
Tools (no. of specimens $=3$ )

A distal end of an Archaic period dart point was recovered from the surface, several hundred $\mathrm{m}$ from the mound and Area A. An unidentifiable tool fragment was found between $0-50 \mathrm{~cm}$ bs in shovel test 8 , while an Alba arrowpoint (Figure 4) came from 30-50 $\mathrm{cm}$ bs in shovel test 11 . The Alba arrowpoint was manufactured on a heat-treated Ogallala quartzite.

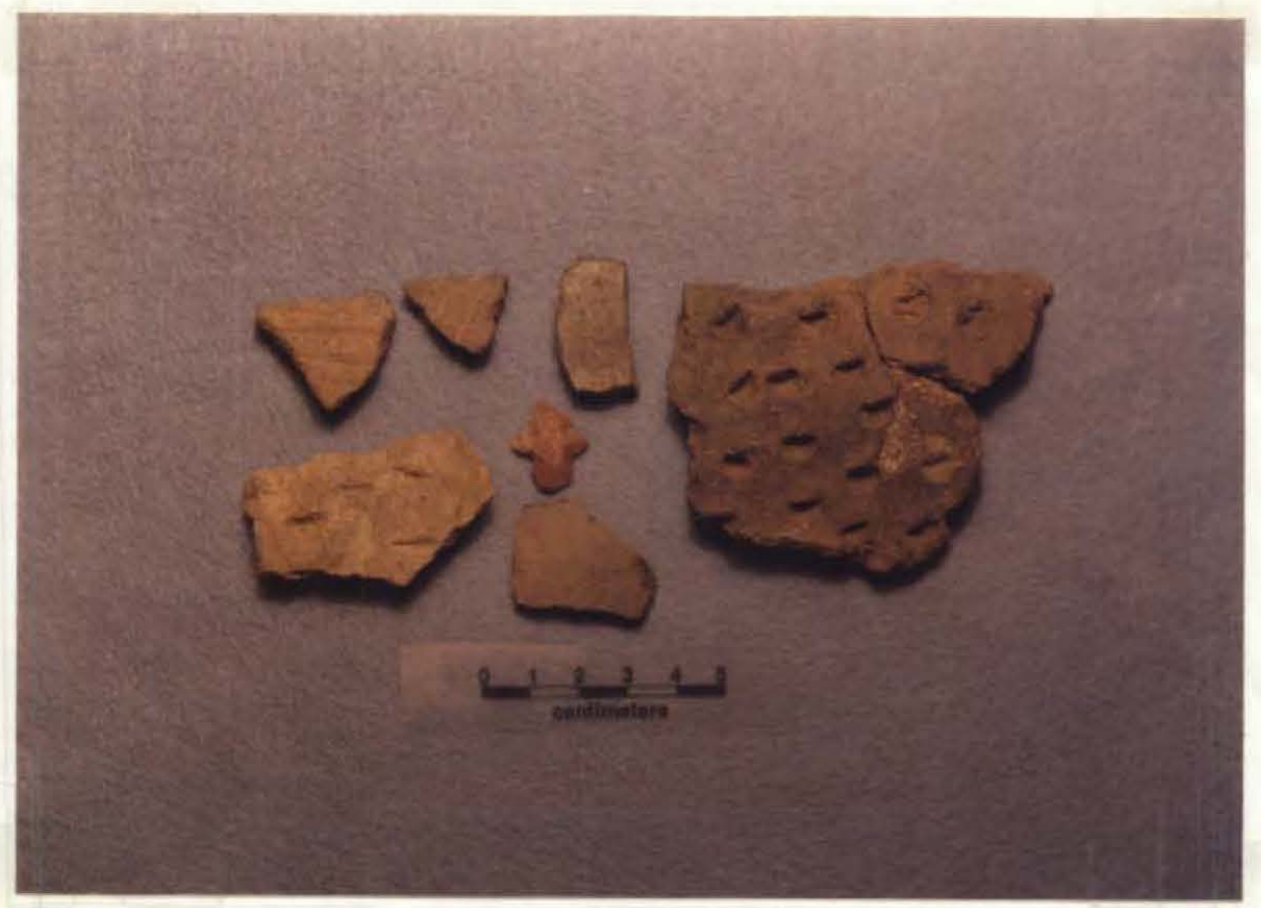

Figure 4. Selected Artifacts recovered from the 1993 investigations at the Z.V. Davis-McPeek site.

Faunal Remains (no. of specimens=32)

A small amount of burned and unburned faunal remains were found in shovel tests on both Area A and B knolls (see Table 1). In shovel test 1,26 of 27 pieces of fauna --all unidentifiable-- were recovered between $30-50 \mathrm{~cm}$ bs. Bone was found between 0-50 $\mathrm{cm}$ in shovel test 11 in Area B; three of the faunal remains in this shovel test were burned. 
Charcoal (no. of specimens $=12$ ) and Charred Nutshells (no. of specimens $=10$ )

Preserved pieces of charred nutshell and charcoal were present in seven of the 11 shovel tests with cultural materials. Shovel tests 1,8 , and 10 each had more than four pieces of charcoal and/or charred nutshell. These pieces presumably represent food refuse, the by-products of cooking activities, and remnants of fires.

Daub/Burned Clay (no. of specimens=488)

A large amount of daub and burned clay were found in the 1993 shovel testing at the Z.V. Davis-McPeek site (Figure 5). Most of the daub and burned clay was recovered in shovel tests $1,7-9$ in Area A, generally at depths between $0-50 \mathrm{~cm}$ bs. The daub is uniformly small in size, with amorphous impressions of grasses and sticks.

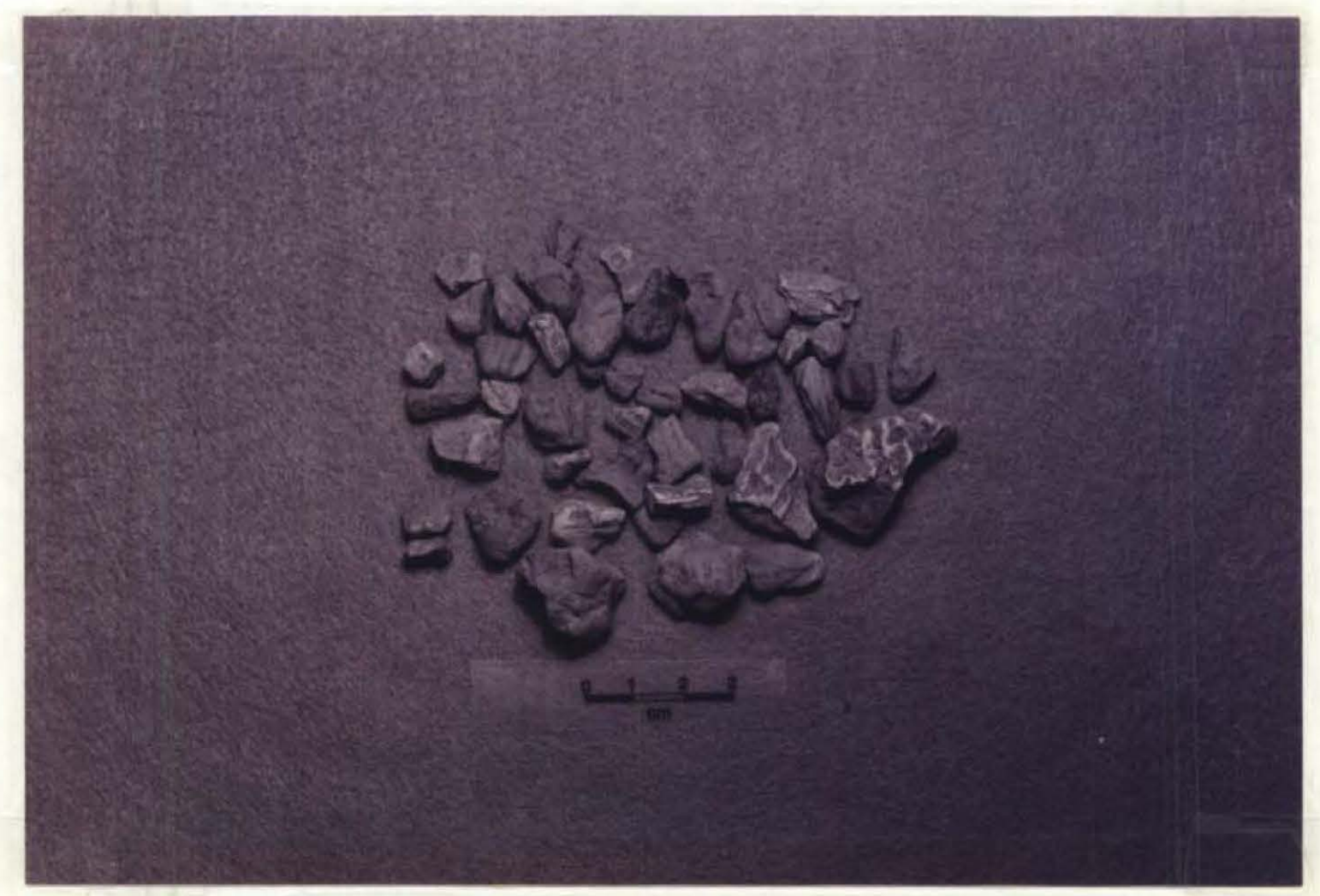

Figure 5. Daub from 1993 Investigations at the Z.V. Davis-McPeek Site. 
The daub represents fired pieces of mud or clay that had been placed along the walls of structures. When the structure(s) burned, the mud (and any impressions of sticks, leaves, and twigs) would have been baked, preserving the impressions of other materials in the pieces of daub.

Pottery Sherds (no. of specimens $=76$ )

The pottery sherds from the Z.V. Davis-McPeek site are from well-made bowls and jars tempered with mixtures of grog, grit, and bone. The vessels are occasionally polished, with body thicknesses generally ranging between $4-7 \mathrm{~mm}$; none of the sherds have slips.

Among the sherds from the shovel testing were three rim sherds. The first (in shovel test 1 ) is from a plain bowl with a slightly inverted rim. The rim sherd from shovel test 10 has a diagonal incised motif (see Figure 4); it is $6 \mathrm{~mm}$ in thickness at the lip. The third rim is from shovel test 11 . This rim is plain with an inverted rim that is $4.5 \mathrm{~mm}$ thick.

Nine of the 70 body sherds have either punctated ( 55 percent; from shovel tests 2 , 7 , and 11) or incised ( 45 percent; from shovel tests 7,8 , and 10) decorations. Because the sherds are rather small, decorative motifs are difficult to discern. Both diagonal and horizontal incised sherds are present, while the punctated sherds are represented by roughly parallel fingernail and tool-impressed punctates on the bodies of the vessels (see Figure 4). The assortment of decorated sherds is similar to that seen in the Woolsey and Wood County Archaeological Survey collections from the site.

Of the varying mixtures of tempers used as alastics in the 1993 collections, bone (23 percent) is the most common temper. Next in frequency is grit (17 percent), followed by grog and grog-grit-bone (16.2 percent), grit-bone (13.7 percent), grog-grit (9.6 percent), and grog-bone (2.7 percent). 
needed to broaden our understanding and knowledge of Early Caddoan peoples in the Little Cypress basin.

\section{ACKNOWLEDGMENTS}

We thank Mike Turner for his considerable assistance in the field work at the site, Bob D. Skiles for loaning us his collections from the site, and Mr. Bryon Spencer and Bobby Mayberry for permission to conduct the investigations.

\section{REFERENCES}

Davis, Hester A., Don G. Wyckoff, and Mary A. Holmes (editors)

$1971 \quad$ Proceedings of the Seventh Caddo Conference. Occasional Publications 1. Oklahoma Archeological Survey, University of Oklahoma, Norman.

Guy, Janice A.

1990 Previous Archeological Investigations. In Archeology and Bioarcheology of the Gulf Coastal Plain, by Dee Ann Story, Janice A. Guy, Barbara A. Burnett, Martha D. Freeman, Jerome C. Rose, D. Gentry Steele, Ben W. Olive, and Kevin J. Reinhard, pp. 27-130. Research Series No. 38. Arkansas Archeological Survey, Fayetteville.

Horizon Environmental Services, Inc. 1992 Cultural Resources of the Proposed Lake Gilmer Project, Upshur County, Texas. Horizon Environmental Services, Inc., Austin.

Kenmotsu, Nancy A., Timothy K. Perttula, William A. Martin, and James E. Bruseth with a contribution by Bonnie Yates

1992 Archeological Investigations at Fort Davis (41SE289), A Family Fort in Stephens County, Texas. Cultural Resource Management Report 2. Department of Antiquities Protection, Texas Historical Commission, Austin.

Perttula, Timothy K.

1984 Patterns of Prehistoric Lithic Raw Material Utilization in the Caddoan Area: The Western Gulf Coastal Plain. In Prehistoric Chert Exploitation: Studies from the Midcontinent, edited by Brian M. Butler and Ernest E. May, pp. 129-148. Occasional Paper No. 2. Center for Archaeological Investigations, Southern Illinois University at Carbondale.

1993 The Development of Agriculture in Northeast Texas before A.D. 1600. In Archeology in the Eastern Planning Region, Texas: A Planning Document, edited by Nancy Adele Kenmotsu and Timothy K. Perttula, pp. 121-146. Cultural Resource Management Report 3. Department of Antiquities Protection, Texas Historical Commission, Austin. 